DOI: http://dx.doi.org/10.24042/alidarah.v8i2.3159

\title{
PENGARUH ENTREPRENUERSHIP KEPALA SEKOLAH TERHADAP EFEKTIFITAS SEKOLAH DI SEKOLAH MENENGAH KEJURUAN NEGERI KOTA PEKANBARU PROVINSI RIAU
}

\author{
Irawati, Nurhayati Zein, Wardani Purnama Sari \\ Fakultas Tarbiyah dan Keguruan UIN Sulthan Syarif Kasim Riau \\ irasofyanpku@gmail.com
}

\begin{abstract}
Abstrak
Tujuan penelitian ini adalah untuk mengetahui Pengaruh Entrepreurship Kepala Sekolah terhadap Efektifitas Sekolah di Sekolah Menengah Kejuruan Negeri Kota Pekanbaru Provinsi Riau. Teknik analisa data, peneliti menggunakan teknik regresi linear sederhana. Berdasarkan analisis data, maka dapat disimpulkan bahwa pengaruh Entrepreurship Kepala Sekolah terhadap Efektifitas Sekolah di Sekolah Menengah Kejuruan Negeri Kota Pekanbaru Provinsi Riau dilihat dari persamaan $\hat{\mathrm{Y}}=3,885+0,721 \mathrm{X}$. Artinya setiap terjadi penambahan satu-satuan pada variabel $\mathrm{X}$ (entrepreneurship), maka terjadi kenaikan pada variabel Y (efektifitas) sebesar 0,721 . Dan untuk melihat signifikan korelasi dari kedua variabel tersebut dengan pada taraf Koefesien korelasi nya 0,878 Interpretasikan besarnya koefisien korelasi dengan menggunakan tabel nilai " $\mathrm{r}$ " Product Moment pada taraf signifikan $5 \%$ adalah $0,250 \mathrm{rt}=$ pada taraf signifikan $1 \%$ adalah 0,32 . Ro (observasi) $=0,894$ bila dibandingkan $\mathrm{rt}$ (tabel) pada taraf signifikan $5 \%(0,894>0,250)$ ini berarti $\mathrm{Ha}$ diterima, Ho ditolak. Koefisien korelasi $\mathrm{r}$ adalah 0,894 . R Square 0,799 jadi Kontribusi entrepreneurship terhadap efektifitas adalah sebesar 0,799X 100 $=79,9 \%$. Kesimpulannya adalah terdapat pengaruh yang signifikan entrepreneurship terhadap efektifitas dapat diterima, dengan sendirinya Ho ditolak.
\end{abstract}

Kata Kunci: Entrepreneurship, Efektifitas 


\section{PENDAHULUAN}

Kepemimpinan yang efektif dari suatu lembaga pendidikan merupakan tolak ukur kinerja seorang kepala sekolah. Alasannya kepala sekolah memiliki peran yang sangat kuat dalam mengkoordinasikan, menggerakkan, dan menyerasikan semua sumber daya pendidikan yang dimiliki. Oleh karenanya kepala sekolah dituntut mempunyai kemampuan manajemen dan kepemimpinan yang mumpu sehingga mampu mengambil inisiatif dan prakarsa untuk meningkatkan mutu sekolah.

Melalui kemampuan manajerial kepala sekolah mampu mempengaruhi dan mentukan kualitas pendidikan, hal ini disebabkan oleh karena manajemen sekolah secara langsung mempengaruhi dan menentukan efektif atau tidaknya kurikulum, berbagai peralatan belajar, waktu mengajar dan proses pembelajaran. Karena itu kepala sekolah perlu memiliki kemampuan untuk memberdayakan seluruh sumber daya manusia yang ada untuk mencapai tujuan sekolah. Kepala sekolah harus memiliki kemampuan untuk meningkatkan sumber daya manusia (guru), kepala sekolah yang hebat harus menjadi model bagi sekolah termasuk guru dan siswa dengan memberikan contoh mengembangkan diri secara terus menerus lewat kegiatan manajemen sekolah yang baik.

Secara konseptual sorang kepala sekolah memang seyogyanya: (1) memiliki pandangan jauh kedepan (visi) dan tahu tindakan apa yang harus dilakukan (misi) serta paham tentang cara yang akan dilakukan (strategi). (2) memiliki kemampuan mengkoordinasikan sumberdaya yang terbatas untuk mencapai tujuan (3) memiliki kemampuan mengambil keputusan secara cepat, tepat dan akurat (4) memiliki kemampuan memobilisasi sumberdaya yang ada untuk mencapai tujuan dan mampu menggugah pengikutnya untuk melakukan hal-hal yang penting untuk tujuan sekolah (5) memiliki kemampuan memerangi ketidak pedulian, kecurigaan, tidak membuat keputusan. Seorang kepala sekolah dalam melaksanakan tugasnya menjadikan sekolah yang efektif sangat membutuhkan bantuan dari segala lini dalam sekolah tersebut.

Seorang kepala sekolah dalam melaksanakan tugasnya menjadikan sekolah yang efektif sangat membutuhkan bantuan dari segala lini dalam sekolah tersebut. Seperti yang penulis dapatkan dari wawancara awal dengan bebarapa kepala sekolah dan beberapa orang guru dari sekolah SMK Negeri maupun SMK Swasta bahwa efektifitas sekolah ini belum sepenuhnya dapat terlaksana dengan baik hal ini di karenakan kepemimpinan kepala sekolah belum seiring dengan kemampuan manajerial yang baik dan dapat berakibat kepada tata kelolah sekolah termasuk penguasaan sistem pembiayaan dan kemampuan kewirausahaan belum berjalan dengan baik sehingga kepala sekolah tersebut belum mampu sepenuhnya menciptakan budaya dan iklim 
yang kondusif, pemberdayaan sumber daya yang belum maksimal, penyusunan perencanaan yang belum maksimal, pengelolaan tata keuangan dan pembiayaan yang belum maksimal, belum maksimalnya kemampuan menciptakan inovasi dalam pengembangan sekolah.

Dari pra survei yang penulis lakukan kepada kepala sekolah terlihat kecenderungan tidak efektifnya pengelolaan sumber daya, hal tersebut dapat dilihat dari: (1) guru-guru tidak mengajar pada bidangnya sehingga terjadi mis-link dan mis-mactch terhadap siswa (2) tidak terdapatnya tata disiplin kerja yang baik untuk guru, pegawai tata usaha dan pelajar, (3) masih lemahnya kemampuan memimpin kepala sekolah, (4) pendelegasian wewenang kurang jelas (5) belum melibatkan orang tua dan masyarakat secara maksimal dalam membantu pendidikan anak didik (7) Kurikulum belum terintegrasi satu dengan yang lain (8) belum mampunya mengelola keuangan dan pembiayaan sekolah dengan baik serta (9) kemampuan kewirausahaan yang masih rendah sehingga kemandirian dan kemajuan sekolah belum terwujud dengan maksimal.

Secara teori banyak fakta yang menyebabkan terjadinya ketidak efektifan sekolah antara lain: (1) aspek kurikulum, sekolah belum mencantumkan tujuan sekolah yang akan dicapai dan belum diiringi dengan rencana dan program yang baik. (2) aspek pengambilan keputusan belum melibatkan guru, staf, dan masyarakat dalam pengambilan keputusan. (3) aspek sumber, belum adanya sumber yang memadai di sekolah, sehingga belum memungkinkan guru untuk mengajar dengan efektif, dan sekolah belum mempunyai guru yang kapabel dan bermotivasi tinggi. (4) aspek hasil belajar nilai tes belum menunjukkan tingkat pencapaian hasil belajar. (5) aspek kepemimpinan, belum adanya pembagian tanggung jawab dan belum adanya pengelolaan sumber daya dengan efisien. (6) dari aspek iklim sekolah yang belum mampu terjaga dengan baik. Oleh karena itu, penulis tertarik untuk menulis tentang "Pengaruh entreprenuership kepala sekolah terhadap efektifitas sekolah di Sekolah Menengah Kejuruan Negeri Kota Pekanbaru Propinsi Riau.

Berdasarkan pada uraian latar belakang di atas, maka rumusan masalahnya adalah sejauh mana pengaruh entrepreneursip kepala sekolah terhadap efektifitas sekolah di SMKN Kota Pekanbaru Propinsi Riau?

\section{Efektifitas Kepala Sekolah}

Miller mengemukakan "Effectiveness be define as degree to which a social system achieve its goals.Effectiveness must be distinguished from efficiency. Efficiency is mainly concerned withwith goal attainment." Efektifitas merupakan tingkat seberapa jauh suatu sistem sosial mencapai tujuannya. Efektifitas ini harus dibedakan dengan efisiensi. Efisiensi terutama 
mengandung pengertian perbandingan antara biaya dan hasil, sedangkan efektifitas secara langsung dihubungkan dengan pencapaian suatu tujuan.

Draf mengatakan, "Effectiveness is degree to which the organizational achieves a state goal". Efektifitas adalah tingkat ketercapaian tujuan organisasi. Mulyasa mengemukakan efektifitas adalah bagaimana suatu organisasi berhasil mendapatkan dan memanfaatkan sumberdaya dalam usaha mewujudkan tujuan operasional. Sedangkan Menurut Komariah, Efektifitas adalah ukuran yang menyatakan sejauh mana sasaran atau tujuan (kuantitas, kualitas, dan waktu) dicapai. Dalam bentuk persamaan, efektifitas adalah sama dengan hasil nyata dibagi dengan hasil yang diharapkan.

Berdasarkan pengertian di atas dapat dikemukakan bahwa efektifitas berkaitan dengan ketercapaian tujuan, ketepatan waktu, pemanfaatan sumber daya dan adanya partisipasi aktif dari anggota dalam hal ini adalah kepala sekolah dan warga sekolah. Efektifitas menurut Gibson memiliki tiga kriteria yang harus ada pada manajer, yaitu sebagai berikut: (1) Kriteria efektifitas jangka pendek, (2) Kriteria efektifitas jangka menengah (3) Kriteria efektifitas jangka panjang. Kriteria efektifitas jangka pendek yaitu, produksi, mutu, efisiensi, flesibilitas, dan kepuasan. Kriteria efektifitas jangka Menengah yaitu adanya persaingan dan pengembangan, sedangkan kriteria efektifitas jangka panjang yaitu untuk menentukan kelangsungan hidup organisasi / lembaga.

Dengan adanya kriteria efektifitas di atas maka seorang kepala sekolah dapat merencanakan program kerja yang ingin dicapai. Program kerja yang dirancang tersebut harus sesuai dengan sasaran dan tujuan anggota kelompok kerja. Efektif atau tidak efektifnya suatu organisasi sekolah tergantung pada berbagai faktor, diantaranya anggota kelompok,pemimpin kelompok, fasilitas/sarana dan prasarana, kejelasan tujuan, dan ketepatan menelaah tugas. Tetapi yang paling menentukan adalah pimpinan kekompok. Kepala sekolah sebagai pimpinan kelompok kerja yang akan memegang kunci suatu efektifitas kerja. Secara umum menurut Riyanto efektifitas suatu unit kerja akan ditentukan oleh tiga faktor yaitu: (1) manusia atau sumber daya manusia (2) tujuan atau sasaran (3) proses pencapaian tujuan.

Menurut Abin dalam supardi mengatakan bahwa efektifitas sekolah pada dasarnya menunjukkan tingkat kesesuaian antara hasil yang dicapai berupa achievement atau observed outputs dengan hasil yang diharapkan berupa objectives, target, intended output sebagaimana telah ditetapkan. Departemen Pendidikan Nasional (Depdiknas), sekolah dikatakan baik/efektif apabila memiliki delapan kriteria: (1) Siswa yang masuk terseleksi dengan ketat dan dapat dipertanggungjawabkan berdasarkan prestasi akademik, psikotes, dan tes fisik, (2) sarana dan prasarana pendidikan terpenuhi dan kondusif bagi pembelajaran, (3) iklim dan suasana mendukung untuk kegiatan belajar, (4) guru dan tenaga kependidikan 
memiliki profesionalisme yang tinggi dan tingkat kesejahteraan yang memadai, (5) melakukan inprovisasi kurikulum sehingga memenuhi kebutuhan siswa yang pada umumnya memiliki motivasi belajar yang tinggi dibandingkan dengan siswa seusianya, (6) proses pembelajaran lebih berkualitas dan dapat dipertanggungjawabkan kepada siswa maupun wali siswa dan (8) sekolah unggul bermanfaat bagi siswa dan lingkungannya

Hal sama juga disampaikan Burstein, Linn dan Capel dalam Supardi bahwa sekolah efektif mengandung dua dimensi yaitu kualitas dan ekuitas. Kualitas, sekolah dapat meningkatkan pencapaian akademik peserta didik dan ekuitas, sekolah dapat menampung peserta didik dari kalangan miskin. Berdasarkan kepada beberapa pendapat para ahli yang sudah dijelaskan maka penulis dapat menyatakan bahwa efektifitas sekolah adalah suatu keadaan yang tercapainya tujuan sekolah yang diharapkan atau dikehendaki melalui pekerjaan sesuai dengan rencana yang telah ditentukan.

Dari uraian di atas maka dapat disimpulkan bahwa efektifitas sekolah adalah keadaan yang menunjukkan ketercapaian suatu tujuan yang telah ditetapkan sebelumnya melalui aktifitas- aktifitasnya. Hal ini dapat dilihat melalui indikator: (1) kegiatan untuk ketercapaian dan tujuan sekolah dinyatakan secara jelas dan spesifik, (2) pemanfatan waktu, (3) penggunaan fasilitas / sarana dan prasarana yang tepat, dan (4) penyusunan program yang tepat, (5) kepemimpinan instruksional, (6) manajemen berbasis sekolah, (7) adanya sumber daya yang memadai di sekolah, sehingga memungkingkan guru dapt mengajar dengan efektif..

\section{Entrepreneurship Kepala sekolah}

Coulter dalam zubin setha dan Rosalind Jones, Paul harrigan bahwa: entrepreneurship is proscess whereby an individual or group of individuals use organized effort and means to pursue opportunities to create value and grow by fulfilling want and need through innovation and uniqueness, no matter what resources are currently controlled. Hal yang sama juga di kemukakan oleh Mark Casson entrepreneurship pada dasarnya adalah konsep dasar yang menghubungkan berbagai disiplin ilmu yang berbeda antara lain ekonomi, sosiologi, dan sejarah. Entrepreneurship bukanlah hanya bidang interdisiplin yang biasa kita lihat, tetapi adalah pokok-pokok yang menghubungkan kerangka-kerangka konseptual utama dari berbagai disiplin ilmu. Tepatnya dapat dianggap sebagai kunci dari blok bangunan yang terintegrasi. Pendapat yang sama juga dikemukakan oleh suryana bahwa yang dikatakan dengan entrepreneurship/ kewirausahaan adalah kemampuan berfikir kreatif dan inovatif yang dijadikan sebagai dasar, kiat dan sumber daya untuk mencari peluang menuju sukses. Inti dari kewirausahaan adalah kemampuan untuk menciptakan sesuatu yang baru dan berbeda (Create and 
different) melalui berfikir kreatif dan bertindak inovatif untuk menciptakan peluang.

Dalam kehidupan organisasi atau lembaga, karya dan karsa hanya terdapat pada orang-orang yang berfikir kreatif. Tidak sedikit orang yang berhasil meraih sukses karena memiliki kemampuan kreatif dan inovatif. Proses kreatif dan inovatif ini diawali dengan munculnya ide-ide dan pemikiran-pemikiran baru untuk menciptakan sesuatu yang baru dan berbeda. Sedangkan pada lembaga atau organisasi proses kreatif dan inovatif dilaksanakan melalui kegiatan penelitian dan pengembangan (reseach and development ) untuk meraih pasar. Sesuatu yang berbeda tersebut akan mempunyai nilai tambah barang atau jasa yang menjadi sumber keunggulan yang dijadikan peluang.

Definisi entepreneurship/kewirausahaan menurut E. Rye dalam Irianto adalah suatu pengetahuan terapan dari konsep dan teknik manajemen yang disertai resiko dalam merubah atau memproses sumber daya menjadi output yang bernilai tambah tinggi (value edded).Perubahan ini dilakukan melalui menciptakan deferensiasi, standarisasi, proses dan alat desain dalam menciptakan pasar dan pelanggan baru.

Selain itu definisi kewirausahaan menurut Instruksi Presiden Reublik Indonesia (INPRES) No. 4 Tahun 1995 tentang Gerakan nasional Memasyarakatkan dan Membudayakan kewirausahaan adalah semangat, sikap, perilaku dan kemampuan seseorang dalam menangani usaha dan/atau kegiatan yang mengarah pada upaya mencari menciptakan, menerapkan cara kerja, teknologi dan produk baru dengan meningkatkan efesiensi dalam rangka memberikan pelayanan yang lebih baik dan atau memperoleh keuntungan yang lebih besar. Karakteristik yang dimiliki oleh seorang wirausaha dalam memenuhi syarat-syarat keunggulan bersaing bagi perusahaan/organisasi seperti inovatif, kreatif, adaptif, dinamik, kemampuan berintegrasi, kemampuan mengambil resiko atas keputusan yang dibuat, integritas, daya juang, dan kode etik niscaya mewujudkan efektifitas perusahaan/organisasi. Mencermati makna kewirausahaan di atas, dapat dipahami bahwa kewirausahaan dalam pendidikan kerja keras yang secara terus menerus dilakukan pihak sekolah terutama kepala sekolah untuk menjadikan sekolah yang dipimpinnya lebih bermutu. Konsep kewirausahaan ini meliputi usaha membaca dengan cermat peluang-peluang, melihat setiap unsur institusi sekolah adanya sesuatu yang baru atau inovatif, menggali sumber daya secara realistik dan dapat dimanfaatkan, mengendalikan resiko, mewujudkan kesejahteraan dan mendatangkan keuntungan finansial. Kesejahteraan dan keuntungan terutama dilihat untuk kepentingan peserta didik, guru-guru, kepala sekolah, staf, orang tua, pemerintah dan masyarakat sekitar atau masyarakat yang lebih luas lagi. 
Peraturan Menteri Pendidikan Nasional Nomor 13 Tahun 2007 tentang Standar Kepala Sekolah/Madrasah menegaskan bahwa seorang kepala sekolah/madrasah harus memiliki 5 (lima) dimensi kompetensi minimal yaitu: kompetensi kepribadian, manajerial, kewirausahaan, supervisi, dan sosial. Salah satu dimensi kompetensi kepala sekolah adalah kewirausahaan. Kewirausahaan dalam makna untuk kepentingan pendidikan yang bersifat sosial bukan untuk kepentingan komersial. Kewirausahaan dalam bidang pendidikan yang diambil adalah karakteristiknya (sifatnya) seperti inovatif, bekerja keras, motivasi yang kuat, pantang menyerah dan selalu mencari solusi terbaik, dan memiliki naluri kewirausahaan; bukan mengkomersilkan sekolah/madrasah. Semua karakteristik tersebut bermanfaat bagi kepala sekolah dalam mengembangkan sekolah/madrasah, mencapai keberhasilan sekolah, melaksanakan tugas pokok dan fungsi sebagai pemimpin, menghadapi kendala sekolah, dan mengelola kegiatan sekolah/madrasah sebagai sumber belajar siswa.

Manfaat kompetensi kewirausahaan bagi kepala sekolah/madrasah adalah: (1) Mampu menciptakan kreativitas dan inovasi yang bermanfaat bagi pengembangan sekolah/madrasah (2) Bekerja keras untuk mencapai keberhasilan sekolah/madrasah sebagai organisasi pembelajaran yang efektif (3) Memiliki motivasi yang kuat untuk mencapai kesuksesan dalam melaksanakan tugas pokok dan fungsi sebagai kepala sekolah/madrasah (4) Pantang menyerah dan selalu mencari solusi terbaik dalam menghadapi kendala sekolah/madrasah (5) Memiliki naluri kewirausahaan sebagai sumber belajar siswa dan (6) menjadi teladan bagi guru dan siswa di sekolahnya, khususnya mengenai kompetensi kewirausahaan.

Kepala sekolah sebagai seorang wirausahawan yang sukses harus memiliki tiga kompetensi pokok yaitu pengetahuan, keterampilan, dan sikap/sifat kewirausahaan. Ketiga kompetensi tersebut saling berkaitan. Seseorang yang tidak memiliki ketiga kompetensi tersebut akan gagal sebagai wirausahawan yang sukses. Menurut Junus Pendidikan yang diselenggarakan di sekolah yang dipimpin oleh kepala sekolah haruslah berwatakkan kewirausahaan yang dapat ditempuh dengan cara: (1) Membangun keimanan, jiwa dan semangat (2) membangun dan mengembangkan sikap mental dan watak berwirausaha (3) mengembangkan daya pikir dan berfikir wirausaha (4) memajukan dan mengembangkan daya penggerak diri (5) mengerti dan menguasai teknik-teknik menghadapi resiko, persaingan dan suatu proses kerjasama (6) mengerti dan menguasai menjual ide (7) memiliki kemampuan pengurusan atau pengelolaan (8) mempunyai keahlian terentu termasuk bahasa asing.

\section{Kepala Sekolah}


Menurut Supardi Kepala sekolah adalah pimpinan pada sebuah lembaga sekolah yang bertugas memimpim sebuah lembaga sekolah dengan syarat-syarat yang telah ditetapkan. Dalam melaksanakan pekerjaannya sehari-hari seorang kepala sekolah memiliki peran sebagai pimpinan, manajer, dan pengajaran. Jenis kepemimpinan yang dipilih atau diterapkan disesuaikan dengan kondisi dan situasi yang dihadapi di lembaga sekolah masing-masing apakah transaksional, transformasional, atau visioner, gabungan anatara antara dua atau tiganya. Dengan pelaksanaan peran kepemimpinan, manajerial, dan pengajaran yang didukung oleh jenis kepemimpinan transaksional, atau transformasional, dan visioner kepala sekolah akan menjadi efektif. Efektifitas kepemimpinan kepala sekolah akan membawa kepada efektifitas sekolah.

\section{HIPOTESIS}

Ada pengaruh yang positif dan signifikan antara Entrprenuership Kepala Sekolah Terhadap Efektifitas Sekolah.

\section{TEKNIK ANALISA DATA}

Data yang diperoleh peneliti dalam penelitian ini akan diolah dengan menggunakan Analisis Regresi Linier Sederhana dengan bantuan program SPSS.

\section{PEMBAHASAN}

Analisis Deskriptif Kepala SMK Negeri Kota Batam

Statistics

\begin{tabular}{|c|c|c|}
\hline & Efektifitas & Entrepreneurship \\
\hline Valid & 7 & 7 \\
\hline Missing & 0 & 0 \\
\hline Mean & 96.86 & 98.71 \\
\hline Std. Error Of Mean & 6.717 & 6.672 \\
\hline Median & 96.00 & 101.00 \\
\hline Mode & $71^{\mathrm{a}}$ & $75^{\mathrm{a}}$ \\
\hline Std. Deviation & 17.771 & 17.651 \\
\hline Variance & 315.810 & 311.571 \\
\hline Range & 55 & 53 \\
\hline Minimum & 71 & 75 \\
\hline Maximum & 126 & 128 \\
\hline Sum & 678 & 691 \\
\hline Percentiles & 81.00 & 81.00 \\
\hline 50 & 96.00 & 101.00 \\
\hline 75 & 106.00 & 107.00 \\
\hline
\end{tabular}

a. Multiple modex exist The smallest value is shown

Hasil pengumpulan data yang diperoleh menunjukkan bahwa skor empirik terendah yang diperoleh adalah untuk variabel efektivitas 71 dan skor tertinggi 126 , rentang 55, skor total 678 , rata-rata 96.86, standar deviasi 
17.771, modus 71, median 96.86. Sedangkan hasil pengumpulan data yang diperoleh menunjukkan bahwa skor empirik terendah yang diperoleh adalah untuk variabel entrepreneurship 75 dan skor tertinggi 128, rentang 53, skor total 691, rata-rata 98,71, standar deviasi 17.651, modus 75, median 101.

Dengan uji nomalitas akan diketahui sampel yang berasal dari populasi yang berdistribusi normal atau tidak. Apabila pengujian normal, maka hasil perhitungan statistik dapat digeneralisasi pada populasinya. Uji normalitas dilakukan dengan menggunakan komputer program SPSS 22 (Uji Kolmogorov-Smirnov). Kriterianya adalah signifikansi untuk uji dua sisi hasil perhitungan lebih besar dari $>\alpha=0,05$ berarti berdistribusi normal. Hasil pengujian normalitas kedua variabel penelitian disajikan pada tabel berikut ini.

One-Sample Kolmogorov-Smirnov Test

\begin{tabular}{|ll|r|r|}
\hline & & Efektifitas & Entrepreneurship \\
\hline $\mathrm{N}$ & & 7 & 7 \\
Normal & Mean & 92.14 & 93.86 \\
Parameters ${ }^{\mathrm{a}, \mathrm{b}}$ & Std. Deviation & 10.699 & 11.568 \\
Most Extreme & Absolute & .168 & .219 \\
Differences & Positive & .134 & .153 \\
& Negative & -.168 & -.219 \\
Test Statistic & & .168 & .219 \\
Asymp. Sig. (2-tailed) & $.200^{\mathrm{c}, \mathrm{d}}$ & $.200^{\mathrm{c}, \mathrm{d}}$ \\
\hline
\end{tabular}
a. Test distribution is Normal.
b. Calculated from data.
c. Lilliefors Significance Correction.
d. This is a lower bound of the true significance.

Dari tabel pada kolom Sig, diperoleh nilai signifikansi variabel efektifitas (Y) sebesar 2,000, dan variabel entrepreneurship $\left(\mathrm{X}_{2}\right)$ sebesar 2,000. Nilai signifikansi dari masing-masing variabel ini lebih besar daripada nilai $\alpha=0,05$. Dengan demikian, $\mathrm{H} 0$ diterima atau data dari masing-masing variabel berdistribusi normal. Dengan demikian, persyaratan analisis regresi terpenuhi.

Uji Hipotesis yang diuji adalah terdapat pengaruh positif dan signifikan dan entrepreneurship (X) terhadap efektifitas kepala SMK Negeri (Y). Berdasarkan hasil perhitungan dengan SPSS 22, diperoleh koefisien determinasi sebagai berikut: 


\section{Coefficients $^{\mathrm{a}}$}

\begin{tabular}{|c|c|c|c|c|c|}
\hline \multirow[b]{2}{*}{ Model } & \multicolumn{2}{|c|}{ Unstandardized Coefficients } & $\begin{array}{c}\text { Standardized } \\
\text { Coefficients }\end{array}$ & & \\
\hline & $\mathrm{B}$ & Std. Error & Beta & $\mathrm{t}$ & Sig. \\
\hline (Constant) & 3.885 & 6.123 & & .635 & .560 \\
\hline Entrepreneurship & .721 & .350 & .716 & 2.063 & .108 \\
\hline
\end{tabular}

a. Dependent Variable: Efektifitas

Correlations

\begin{tabular}{|ll|r|rr|}
\hline & & KEMAMPUAN & PEMBELAJARAN & \\
\hline Pearson & EFEKTIFITAS & 1.000 & .830 \\
Correlation & .830 & & 1.000 \\
& ENTREPRENURSH & & .000 \\
& IP & .000 & \\
\hline Sig. (1-tailed) & EFEKTIFITAS & 7 & 7 \\
& ENTREPRENURSH & & 7 \\
& IP & 7 & 7 \\
\hline N & EFEKTIFITAS & ENTREPRENURSH & & 7 \\
& IP & & \\
& & & & \\
\hline
\end{tabular}

Berdasarkan data pada table di atas, diperoleh persamaan regresi yang menyatakan ada pengaruh entrepreneurship terhadap efektifitas Ditunjukkan dengan persamaan regresi $\hat{Y}=3,885+0,721 \mathrm{X}$. Artinya setiap terjadi penambahan satusatuan pada variabel $\mathrm{X}$ (entrepreneurship), maka terjadi kenaikan pada variabel $\mathrm{Y}$ (efektifitas) sebesar 0,721.

Dari hasil perhitungan diperoleh nilai r (Pearson Correlation) 0,830 dengan tingkat probabilitas 0,000 . Oleh karena probabilitas lebih kecil dari 0,05 maka H0 ditolak, artinya ada pengaruh antara entrepreneurship terhadap efektifitas kepala sekolah.

\begin{tabular}{|l|c|r|r|r|}
\hline Model & \multicolumn{1}{|c|}{ R } & \multicolumn{1}{c|}{ R Square } & \multicolumn{1}{c|}{ Adjusted R Square } & Std. Error of the Estimate \\
\hline 1 & $.894^{\mathrm{a}}$ & .799 & .982 & 2.403 \\
\hline
\end{tabular}

a. Predictors: (Constant), ENTREPRENEURSHIP

b. Dependent Variable: EFEKTIFITAS

Koefesien korelasi nya 0,878 Interpretasikan besarnya koefisien korelasi dengan menggunakan tabel nilai "r" Product Moment. Df $=\mathrm{N}-\mathrm{nr}$ Df $=55 . \mathrm{rt}=$ pada taraf signifikan $5 \%$ adalah $0,250 \mathrm{rt}=$ pada taraf signifikan $1 \%$ adalah 0,32. Ro (observasi) $=0,894$ bila dibandingkan rt (tabel) pada taraf signifikan 5\%(0,894> 0,250) ini berarti Ha diterima, Hoditolak..ro(observasi) 0,894 bila dibandingkan rt (tabel) pada taraf signifikan $1 \%(0,894>0,325)$ ini berarti Ha diterima, H0 ditolak. Koefisien korelasi r adalah 0,894. R Square 
0,799 jadi Kontribusi entrepreneurship terhadap efektifitas adalah sebesar $0,799 \mathrm{X} 100=79,9 \%$. Artinya terdapat pengaruh yang signifikan entrepreneurship terhadap efektifitas dapat diterima, dengan sendirinya $\mathrm{H} 0$ ditolak.

\section{PENUTUP}

Ada pengaruh yang signifikan antara Hal ini dapat dilihat dari besarnya Entrprenuership Kepala Sekolah Terhadap Efektivitas Sekolah di Sekolah Menengah Kejuruan Negeri Kota Pekanbaru Provinsi Riau. Bagi kepala sekolah hendak nya membudayakan jiwa wirausaha di sekolah secara teratur terutama di sekolah menengah Kejuruan. Jiwa Enterpenuership Kepala Sekolah terutama di SMK untuk menunjang skill output lulusan SMK, sehingga bias masuk kedunia kerja.

\section{DAFTAR PUSTAKA}

Aan komariah dan Cepi triatna, 2004, Visionary Leadership, Penerbit Aksara, Jakarta.

Barnawi dan M. Arifin, 2012, Buku Pintar Mengelola Sekolah Swasta, Arruzz media, Jogyakarta.

Budi Astuti, 2007, Pengembangan SDM menuju Pendidikan Berkualitas, http://staff.uny.ac.id/sites/default/files/Pengembangan\%20SDM\%20

Menuju\%20Pendidikan\%20Berkualitas.pdf (diakses 10/03/2014 senin pukul 23:40)

Dadang Suharlan, dkk, 2012, Ekonomi dan Pembiayaan Pendidikan Alfabeta, Bandung.

Daryanto, 2011, Kepala Sekolah Sebagai Pemimpin Pembelajaran, cetakan I, Gava media Yoyakarta.

Draft L. Richard., 2010, New Era Of Management Cengange Learning, Canada.

Dewi Susita, Jurnal, Pengaruh sikap kewirausahaan, kepribadian, kepuasan kerja, dan komitmen, terhadap efektivitas kerja karyawan kementrian perindustrian.

http://educ.utm.my/wpcontent/uploads/2013/11/54.pdf (di akses 21 februari 2014 jam 0.05 )

Dody S Truna, Rudi Ahmad, 2013, Paradigma Pendidikan Berkualitas, Pustaka Setia, Bandung. 
Elchanan Chon and Terry G Gaeske,2004, The economics of education,thirt edition, Thomson south wesren, Stanford USA

Eti Rocheaty, dkk, 2009, Sistem Informasi Manajemen Pendidikan, Bumi Aksara, Jakarta.

Depdikbud, 2007, Kamus Besar Bahasa Indonesia, Balai pustaka, Jakarta.

Gison Ivancevich Donnelly, 2008, Organisasi, Binarupa Aksara, Jakarta

Hamzah B. Uno, 2007, Profesi Kependidikan, Bumi Aksara, Jakarta.

Hessel Nogi, 2005, Manajemen Publik, PT Grasindo.Jakarta

Direktorat Tenaga Kependidikan, , Kementrian pendidikan Nasional. , 2010,

Kewirausahaan, Materi Pelatihan Penguatan Kemampuaan Kepala Sekolah, Direktorat Jenderal Peningkatan Mutu Pendidikan dan Tenaga kependidikan, Jakarta.

Mahmud, 2011, Metode penelitian pendidikan, Pustaka setia, Bandung.

Mark Casson, 2012, Entrepreneurship, teori Mark Casson, 2012, Entrepreneurship, teori, jejaring, sejarah, PT. Raja Grafindo Persada, Jakarta.

Mulyasa, 2011, Manajemen Berbasis Sekolah, PT Remaja Rosdakarya,Bandung.

Mulyono, 2010, Konsep pembiayaan pendidikan, Ar-Ruzz Media, Jogyakarta.

Nanang Fatah, 2012, Standar Pembiayaan Pendidikan, Remaja Rosdakarya, Bandung.

Suryana, 2013, Kewirausahaan pedoman praktis, Kiat dan proses Menuju sukses, Salemba emapat,Jakarta.

Syaiful Sagala, 2010, Supervisi Pembelajaran Dalam Profesi Pendidikan, CV. Alfabeta, Bandung.

Theo Riyanto dan Martinus, 2008, Kelompok Kerja yang Efektif, Kanisius, Yogyakarta.

Thomas W. Zimmrer dan Norman M Scarborough, 2008, Kewirausahaan dan manajemen usaha kecil, edisi 5 Salemba empat,Jakarta.

Undang-undang Republik Indonesia Nomor 20 Tahun 2003 tentang Sistem Pendidikan, Citra umbara, Bandung. 